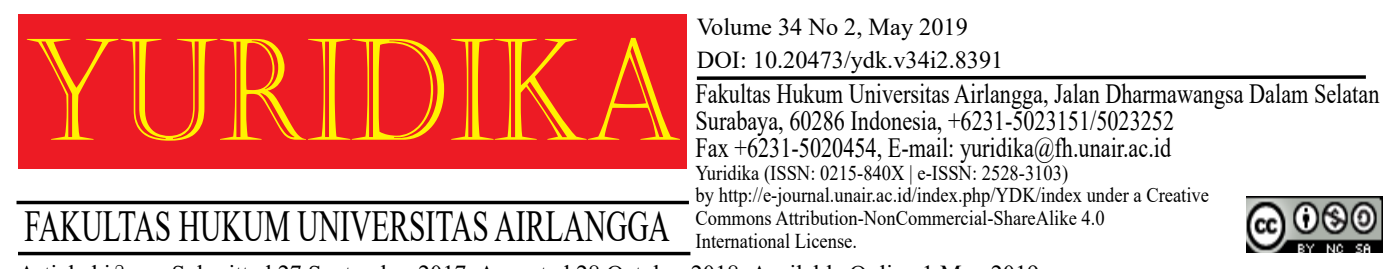

Article history: Submitted 27 September 2017; Accepted 28 October 2018; Available Online 1 May 2019

\title{
Non-Profit Nature of Associations (Vereniging)
}

\author{
Paula \\ paula.listyana@gmail.com \\ Universitas Pelita Harapan Surabaya
}

\begin{abstract}
Association (vereniging) is regulated briefly by Indonesia civil code and Stb. 1870 No. 64. There are no restriction on the purpose of establishing an association, other than by law, public order and morality. The purpose of association, which is not to seek profit, or often referred to as a nonprofit goal, is obtained from doctrine. However, there is no common understanding among law experts and practitioners regarding the notion of non profit goal and its implications. On the other hand, the role of associations in society is increasing significantly. The purpose of an association determines the scope of its activity and its governance. Therefore, this research aims to find the purpose and activities of association. This research is a doctrinal research using statue, conceptual, historical, and comparative approach. The result of this research is the term of 'not to seek profit' or 'non-profit' goal of association should be understood as the purpose other than obtaining profit for-and therefore distributing it to-its members. Associations can engage in profit-making activities as long as it complies with certain restrictions.
\end{abstract}

Keywords: Association; Vereniging; Profit-Making Activity; Non Profit.

\section{Introduction}

Many people gather to work together to achieve certain goals, such as mantaining family relationship, developing hobbies, and enhancing knowledge, as well as to conduct business for the sake of profit. In the legal literature, a gathering of people for a common purpose, in a broad sense, is called 'association'. The term 'association' in a narrow sense refers to the association governed in Indonesia civil 
code $^{1}$ Book III Chapter IX, Stb. 1870 No. $64^{2}$ and Stb. 1939 No. 570 jo. $717 .{ }^{3}$ Article

1653 Indonesia civil code specifies as follows:

"In addition to an actual partnership (eigenlijk maatschap), associations of persons (vereniging van personen) as a legal entities are also recognized the law, whether they are established by public authority or acknowledged as such, or whether they are permitted as lawful, or whether they are established with a specific objective, provided that they do not violate the law or morality".

Pursuant to Article 1653 Indonesia civil code, associations (vereniging van personen) can be classified into four types, namely:

a. association founded (ingesteld) by the Government, such as the provincial, district, city, state banks and state enterprises; ${ }^{4}$

b. association recognized (erkend) by the Government, such as church (kerkgenootschap). ${ }^{5}$ Church then specifically regulated by Royal Decree (Koninlijk Besluit) of the Regulation of Legal Status of the Church Society (Regeling van de Rechpositie der Kerkgenootschappen) promulgated in State Gazette 1927 No. 156;

c. associations permitted (geoorloofd toeglaten) by the Government; ${ }^{6}$

d. association founded by people for purposes not contrary to law and morality. ${ }^{7}$

According to the generally accepted doctrine (de heersende leer), the term "association" (vereniging van personen) in civil law refers to association of the fourth type (in point d). That association, which is founded by people for purposes not contrary to law and morality, is the subject of this study. This study does not cover Indonesian association (Inlandsche vereniging) and other associations which

${ }^{1}$ Burgerlijk Wetboek voor Indonesie, State Gazette (Staatsblad) 1847 No. 23.

2 Royal Decree (Koninlijk Besluit) of March 28, 1870 on Legal Personlity of Associations (Rechtspersoonlijkheid van Vereenigingen), State Gazette (Staatsblad) 1870 No. 64. This regulation amends some provisions of Indonesia civil code Book III Chapter IX. This regulation is in concordance of Act on regulation and limitation of the right of association and assembly (regeling en beperking uitoefening van der vereeniging van het recht en vergadering), State Gazette 1855 No. 32, in Netherlands.

${ }^{3}$ State Gazette 1939 No. 570 on Ordinance on Indonesian Association (Ordonantie od de Inlandsche Vereniging) while Gazette 1939 No. 717 contains the Ordinance on Legal Settlement of Indonesian Legal Entities (Ordonantie of de Gerechtelijke Vereffening van Inlandsche Rechtspersonen).

${ }^{4}$ Wirjono Prodjodikoro, Hukum Perkumpulan, Perseroan, Dan Koperasi Di Indonesia (Dian Rakajat 1969).[11].

5 Herlien Budiono, 'Beberapa Catatan Mengenai Perkumpulan', Kumpulan Tulisan Hukum Perdata di Bidang Kenotariatan (Citra Aditya Bakti 2008).[287].

6 ibid.[288].

7 ibid. 
are subject to the customary (adat) law.

According to article 1653 Indonesia civil code as well as Stb 1870 No. 64, associations can be established for all purposes not contrary to law and morality. On the other hand, according doctrine (de heersende leer), it is accepted that associations do not aim for profit (non-profit purpose). However, the meaning of non-profit is not comprehensively explained in legal literatures. As a result, legal experts have different views of the objectives and scope of activities of associations. According to some experts, because associations do not aim for profit then they are forbidden to conduct business. Some view that associations should not charge for activites they conduct. Associations can only hold social activities. Contrary to this view, there is also a view that the association may be founded for the purpose of gaining profit. This view departs from the purpose of association according to Article 1653 Indonesia civil code and how the association is regulated in the book of wealth (Book III Indonesia civil code). In addition, there are other different kind of views from the experts. All this resulted in confusion and uncertainty about the purpose and types of activities of association. Doctrines of associations are not much developed in Indonesia. There are not many legal research on association so far either, therefore, this study is important to eliminate uncertainty and doubt about the purpose of associations. This study examined legal issues as follows: 1) purpose of associations, 2) types of activities of associations. This study is carried out by using statute approach, the conceptual approach, historical approach, and comparative approach.

\section{Associations Are Not Founded to Obtain Profit for Their Members}

The purpose of associations (vereniging), which is not to obtain profit for the members, is derived from comparison of the provisions of partnership (maatschap) and associations in Indonesia civil code, as well as from Indonesia civil code drafting history, customary law, and doctrines. Partnerships (maatschap) is governed in Indonesia civil code Book III Chapter VIII followed by associations in the next chapter under the title of Moral Entities (zedelijk lichamen). This sequential order is regarded by legal experts as deliberately made by the legislators to show the 
differences and similarities between the two. ${ }^{8}$ Partnership (maatschap) according to Article 1618 INDONESIA CIVIL CODE is "an agreement by which two or more individuals bind themselves to contribute something jointly with the intent of sharing the profit therefrom among one another". Deriving from this article, it is inferred that the aim of the founders is to gain profit from the partnership. Therefore, capital contribution (inbreng), whether in form of goods or labor to conduct business activities, is an indispensable element of partnership existence (Article 1619 (2) Indonesia civil code). Profit distribution is an essential element of partnership that the legislators set specific provisions regarding profit and loss sharing among partners (Article 1633 Indonesia civil code) and guarantee every partners get share of profit (Article 1635 Indonesia civil code).

Although Article 1653 INDONESIA CIVIL CODE does not determine that associations (vereniging) are founded for non-profit purpose, it does not specify otherwise either. Furthermore, Chapter IX Book III Indonesia civil code does not contain provisions regarding the obligation of capital contribution (inbreng) and provisions regarding the distribution of profits as in partnerships. Therefore, profit gain and distribution are not essential elements of the association.

The legislators intention that the associations governed by Chapter IX Book III Indonesia civil code are the associations with non-profit purposes (ideëel doel) can be inferred from drafting history of Indonesia civil code. On the 1833 Explanation of Bill of Indonesia civil code Dutch Government states that the common purpose of the founders of association is for entertainment, socializing, charities, and promote the arts and knowledge. However, this sentence was added the words "association for a purpose that is not contrary to law and morality" as the Article 1653 Indonesia civil code today. ${ }^{9}$

Although Article 1653 Indonesia civil code does not prohibit the establishment of an association for the purpose of obtaining benefits for their members, the

${ }^{8}$ W. C. L. Van der Grinten, Vertegenwoordiging En Rechtspersoon: De Rechtspersoon (Hereinafter Referred to as WCL van Der Grinten I) (WEJ Tjeenk Willink 1976).[159].

9 ibid.[125-126]. 
Government approval of the statutes of an association, required by Stb. No. 32 of 1855 in order for an association to be incorporated, has never been given to any association that aim to distribute profits to its members. ${ }^{10}$ An example of refusal of recognition as a legal entity by the authorities was made against Amerongse Crediet Vereniging, the association that provides credit to its members only and distribute profits to members. Valkhoffen and Van der Grinten view that refusal to incorporate the Association is due to association, according to the Stb. 1855 No. 32 , is only allowed to pursue nonprofit goals (ideëel doel). The aim of Amerongse Crediet Vereniging is contrary to the character of association. Huussen-De Groot said that the refusal of the filing was due to the association aims to bring benefits to the members, not the association itself, making it more resembles a partnership than an association. ${ }^{11}$

In 1876 associations founded to obtain profits for their members were separately regulated in Stb. No. 227 and called as cooperative associations (cooperatieve vereniging). ${ }^{12}$ Therefore, an association established with the aim to gain profit for the members is legally not an association (vereniging), but a cooperative. The purpose of establishing associations (vereniging) which is not-for-profit oriented has become a generally accepted doctrine (de heersende leer).

\section{Charity, Religious and Humanitarian Purpose Based on Permenkumham No.} 3 of 2016

Article 1 point 1 of Regulation of the Minister of Law and Human Rights (Peraturan Menteri Hukum dan Hak Asasi Manusia) No. 3 of 2016 on the Procedures for Incorporation and Approval of Amendments of Statutes of Association (Permenkumham No. 3 of 2016) stipulates that the "association is a legal entity,

10 W. C. L. Van der Grinten, Mr. C. Asser's Handleiding Tot de Beoefening van Het Nederlands Burgerlijk Recht: Personenrecht (Hereinafter Referred to as WCL van Der Grinten II) (WEJ Tjeenk Willink 1968).[225-226].

${ }^{11}$ G.J.H. van der Sangen, 'Rechtskarakter En Financiering van de Cooperatie : Een Onderzoek Naar de Civielrechtelijke Kenmerken van de Cooperatie in Het Licht van de Vraag of Daaruit Beperkingen Voortvloeien Voor de Financiering van Haar Ondernemingsactiviteiten' (Universitas Amsterdam 1999).[54-56].

${ }^{12}$ Currently the cooperative is governed by Act No. 25 of 1992 on Cooperatives. 
which is a group of people, established to realize common intent of charity (sosial), religious and humanitarian purpose and does not distribute profits to its members". Permenkumham No. 3 of 2016 does not give definitions of charity, humanitarian and religious purpose.

According to the Indonesian Dictionary (Kamus Besar Bahasa Indonesia), charity (sosial) means liked to look at the public interest (helping, donating, and so on). ${ }^{13}$ Humanity means human nature, is/as human beings. ${ }^{14}$ The term "social" is used interchangeably with amal. Amal is defined as rewarding good deeds (according to Islamic teaching), acts committed with intent to do good to society or human beings (to give alms, to raise funds to help victims of natural disasters, the disabled, and so on). ${ }^{15}$ Alm (derma) is a gift (to the poor and so on) out of generosity; aid money and so forth (to charities and so on). ${ }^{16}$ Those definitions by Kamus Besar Bahasa Indonesia actually does not clearly explain the meaning of charity (sosial), but merely gives a few examples of charity.

In United Kingdom and United Statesm according to Preamble of Charitable Uses Act of 1601 (The Statute of Elizabeth), charity is:

"(The) Relief of aged, impotent, and poor people, (the) maintanance of sick and maimed soldiers and mariners, school of learning, free schools, and scholars in Universities, (the) repair of bridges, ports, havens, causeways, churches, sea-banks and highways, (the) education and preferment of o[r] phans, (the) relief, stock, or maintanace for houses of correction, (the) marriages of poor maids, (the aid) or ease of any poor inhabitants concerning payment of fifteens, setting out of soldiers and other taxes". ${ }^{17}$

However, that stipulation can not be used to decide wheter a giving/donation is a charity or not because that stipulation actually is a general catalogue of charitable purpose. ${ }^{18}$ Judge Lord Macnaghten in Commisioners for Special Purposes of

\footnotetext{
${ }^{13}$ Tim Penyusun Kamus Pusat Pembinaan dan Pengembangan Bahasa, Kamus Besar Bahasa Indonesia (Balai Pustaka 1989).[855].

14 ibid.[558].

${ }^{15}$ ibid. [25].

${ }^{16}$ ibid.[200].

${ }^{17}$ Anwar Borahima, Kedudukan Yayasan Di Indonesia: Eksistensi, Tujuan, Dan Tanggung Jawab Yayasan (Kencana 2010).[97].

${ }^{18}$ Chatamarrasjid Ais, Badan Hukum Yayasan (Revised, Citra Aditya Bakti 2006).[55].
} 
Income Tax v Pemsel [1891] gave four classification of charity, 1) relief of the poor, 2) furthering education, 3) promoting religion, 4) other purposes for public interest. The fourth classification raised problems in concrete cases because it can be intepreted very broadly. ${ }^{19}$ Restatement (Second) of Trust Section 368 attempts to classify charity as follow:

Charitable purposes include:

a) The relief of poverty;

b) The advancement of education;

c) The advancement of religion;

d) The promotion of health;

e) Governmental or municipal purposes; and

f) Other purposes the accomplishment of which is beneficial to the community.

Charity according to those classifications must be of public interest or public benefit. That is, an activity is charitable only if the activity benefits the community in general. This view departs from the point of view of what kind of organization deserves tax-exempt. According to another perspective, all conducts to help people are charitable and humanitarian conducts. ${ }^{20}$ It can be seen that classifying, moreover defining, the words "charity" and "humanity" are difficult things to do. Openended classification, as well as, closed-ended classification raise difficulties in its application. Open-ended classifications, such as Judge Lord Macnaghten's opinion, require interpretation to be applied to concrete matters. It is possible that there are different interpretations in applying that classification to a concrete case. On the other hand, since it is not possible to specify every activity that exists in everyday life, the classification that is limitative or closed-ended will cause the existence of activities that are deemed socially human by the community in general but not recognized by law.

The stipulation of the charitable, religious and humanitarian purpose of association by Permenkumham No. 3 of 2016 is not derived from Acts because INDONESIA CIVIL CODE and S. 1870 No. 64 do not determine the purpose of the

\footnotetext{
${ }^{19}$ ibid.

${ }^{20}$ ibid. [56].
} 
association specifically. This provision of Permenkumham No. 3 of 2016 may have been made by analogizing associations with foundations (yayasan), which were also not established to gain profits. Foundation $\mathrm{Act}^{21}$ regulates that foundations have objectives in the religious, charitable, and humanitarian fields, but as well as Permenkumham No. 3 of 2016, it does not define or classify the activities included in those objectives either.

In reviewing applications to incorporate foundation as a legal entity, the reviewers of Ministry of Law and Human Rights classifed activities of charitable purpose as formal and non-formal education, arts, consumer protection, fostering for narcotics and drug users, establishment and management of orphanages, nursing homes, funeral home, providing coffin for the poor, establishment of hospitals, polyclinics and laboratories. The humanitarian purpose included activities to support the poor, orphans and persons with social problems by establishing care home and other ways, provide natural disaster relief, establish and organize shelters and funeral homes, consumer protection, preserve the environment and provide medical assistance for people who cannot afford it. Later, the classification changed. Activities of charitable purpose are activities of formal and non-formal institution, orphanages, nursing homes, hospitals, polyclinics, and laboratories, sports, science research, comparative studies, and others. The humanitarian sector includes providing relief to natural disaster's victims, war victims, the homeless and the poor, the establishment and operation of shelters and funeral homes, consumer protection, environmental preservation, and others. ${ }^{22}$

This classification is not based on law. People, including legal experts and practitioners, have a diverse understanding of the categories of social and humanitarian activities. As an example, according to classification in United

\footnotetext{
${ }^{21}$ Act No. 16 of 2001 on Foundation, as amended by Act No. 28 of 2004 on the Amendment of Act No. 16 of 2001 on Foundation.

${ }^{22}$ Religious field includes establishing places of worship, organize Islamic school, receiving and distributing charities, infaq, and alms, improving religious understanding, preaching, comparative religious studies, and others.
} 
Kingdom and United States ${ }^{23}$ mentioned previously, education and health are charity. In Indonesia, the opinion is diverse. Some view them as a charity. Some categorize them as humanitarian activities. Some view them as neither charity activities nor humanitarian activity since education and health institutions charge service fee for service rendered. Both the absence of a classification of charitable and humanitarian objectives in the Foundation Act and the stipulation of education as an activity carried out by the foundation through its business entity in Elucidation of Article 8 of Foundation Act, raised an opinion that foundations could no longer provide education. Therefore, Yayasan Pembina Lembaga Pendidikan Persatuan Guru Republik Indonesia (YPLP PGRI), a foundation organizes (PGRI) schools became an association named Perkumpulan Pembina Lembaga Pendidikan Dasar dan Menengah Persatuan Guru Republik Indonesia (PPLP Dasmen PGRI). ${ }^{24}$

The stipulation of the charitable, religious and humanitarian purpose of association by Permenkumham No. 3 of 2016 may lead to a misunderstanding that the classification of charitable, religious and humanitarian objectives for foundation applies the same to the association. In addition to the lack of understanding of classification of social and humanitarian objectives, those classifications are actually inadequate for the association.

\section{Objectives Other than Charitable, Religious, Humanitarian Purpose}

In reality the association objectives are not limited to charitable, religious, and humanitarian purposes as it is stipulated in Permenkumham No. 3 of 2016. Charitable and humanitarian purpose according to the Ministry of Law and Human Rights' classification have to benefit the society. Like there are associations established to give benefits to society, there are associations established to provide (non-monetary)

\footnotetext{
${ }^{23}$ E.g The Statute of Elizabeth dan Restatement (Second) of Trust Section 368.

${ }^{24}$ Novita Risdiana Anggraini Ningsih and Suparwoto, 'Perkumpulan Pembina Lembaga Pendidikan Dasar Dan Menengah Persatuan Guru Republik Indonesia (PPLP Dasmen PGRI) Jawa Timur Tahun 2002-2005' (2014) 2 Avatara.[349-351]. See also Anggela Putri Privitasari, 'Yayasan Pembina Lembaga Pendidikan (YPLP) Pendidikan Tinggi (Dikti) Persatuan Guru Republik Indonesia (PGRI) Provinsi Sumatera Barat 1978-2009' (Universitas Andalas 2011).[9-10].
} 
benefits for their members. Kinship associations, for example, aim to maintain family ties and solidarity of their members of the same tribe. This objective, according to the classification of the Ministry of Law and Human Rights, is neither a charitable nor humanitarian goals since both charitable and humanitarian goals in the classification have an aspect of providing benefits to the society. Apart from the purposes already mentioned, there are associations that aim to provide benefits to both the members and the society. For example, a teacher association aim to improve teachers capability, as well as to enlight the nation by education means.

\section{Proposition for Provision of the Purpose of Association}

Based on the description above, the provision of the purposes of association, which are charity, religious, and humanity, in Permenkumham No. 3 of 2016, is inadequate. Therefore, rather than enumerating the objective of association specifically, the law should stipulated it in restrictive manner, while the definite objectives should be determined by the founders. Besides public order and morality, the restriction of association objective should be on obtaining profit for its members and distributing profit to the members. Hence, the purpose of association could be stipulated by law as follow: the association is founded for a purpose other than obtaining profit for its members.

This stipulation covers a wide range of purposes. It includes charitable, religious, and humanitarian purposes according to the Permenkumham No. 3 of 2016. It also includes the purpose of maintaining fraternity of alumni associations, as well as the purpose of maintaining family ties of kinship associations. Like wise, the purpose of culture preservation of cultural associations is covered by the stipulation. The purpose of professional associations to sustain quality and dignity of the profession are covered as well. In this manner, differences of opinions on purposes that are classified as charitable or humanitarian as of Permenkumham No. 3 of 2016 could be diminished. Legal certainty could be achieved.

Foreign states do not enumerate the purpose of associations specifically. (Nieuw) Burgerlijk Wetboek (N Indonesia civil code) formulates association 
objectives in a restrictive manner so that it can cover a wide range of purpose of associations established in society. According to Article 26 paragraph (1) jo. Article 53 paragraph (1) and (2) Book $2 \mathrm{~N}$ Indonesia civil code, the association has a purpose other than providing material needs of its members and masking an insurance agreement with the members. Likewise, French Act on Associations (Loi du ler juillet 1901 relative au contrat d'association) regulates the purpose of association is not to share profits to its members (Article 1). Supreme Court of Connecticut in First Russian Nat'l Organization, Inc. v. Zuraw case decided that "Voluntary association is ... formed for social, political, moral, religious, benevolent, protective, or mutual purposes, or to promote some public, scientific or educational object, or to facilitate business, and not for purposes of trade or direct pecuniary profit. The term "voluntary associations" often also used interchangeably with the term non-profit organization or not-for-profit organization to distinguish it from the company that aims to make profit for its owners". Uniform Unincorporated Non Profit Association Act adopted in dozens of US states, does not enumerate association objectives as the Supreme Court did. Section 1 of Uniform Unincorporated Non Profit Association Act determines that the association is composed of two or more members join together for purposes other than profit (a common, non-profit purpose).

High Court of Australia in the case of Cameron against Hogan, argued that the association has the goal to ".... to further some common end or interest, the which is the social, sporting, political, scientific, religious, artistic or humanitarian in character, or otherwise stand apart from the monetary gain and material advantage". ${ }^{25}$ The law also regulate the purpose of association in restrictive manner. Section 14 (2) of Associations Incorporation Act regulates that associations that aim to trade or make a profit for its members do not meet the requirements to become a legal entity.

${ }^{25}$ Andrew Twaits, 'The Duties of Officers and Employees in Non-Profit Organizations' (1998) 10 Bond Law Review.[313-314]. 


\section{Types of Activities of Association}

The law does not regulate the activities undertaken by associations. The activities holds by association to achieve its purpose are varied. It can be either free of charge or subject to payment.

\section{a. Activities Organized Without Payment}

Association holds several activities attended by its members as well as non members. Members meeting in general-and indeed should-be held free of charge. The term 'members meeting' here refers to a gathering of members i.e to socialize, as well as a meeting to discuss the activities or conduct of associations. It is not because the members have paid contributions so that the meeting be held free of charge. Rather, it is because associations were established by the founders based on their will to gather and assembly so that members meeting is the essential element of the association. The purpose of associations can not be achieved without a meeting of the members. Hence, the association may not charge admission fee of members meetings, especially the meeting to discuss certain association activity or conduct (usually known as general meeting of members). Sometimes there are cost to hold members meeting, but it should not cause the association to charge admission fee for its members meeting. Therefore, associations should make an effort to have adequate resources to hold members meeting.

In real life, besides members meeting, some associations conduct free-ofcharge events occasionally or regularly, which can be participated both by members and non-members. Some of these events are hold to pursue the association's objectives, while some are hold not to necessarily pursue the objectives of association. A benovalence association which aim for the welfare of the poor, for example, held a free medical treatment, in order to achieve its objectives. On the other hand, a professional association provided disaster relief to victims of natural disasters based on humanitarian grounds.

Fee-of-charge activities can be conducted regulary only if the association has considerable resources (wealth). A substantial amount of monetary resources of 
associations come from membership fees and donations. This kind of funding is not good for longevity of associations since it depends on the fulfillment of obligations of the members and the free will of the giver. Over time, the amount of membership fee set at the establishment of association will no longer be sufficient to finance the association, especially, when the association seeks to develop more programs in order to achieve the association's purpose. Raising the amount of dues can not solve the problem since it can be objected by the association members. Free-of-charge activities reduce associations' wealth. If an association organized all its activities for free, its resources would be depleted. As a result, the creditors of the association would be put on risk. It would threaten the survival of the association as well.

\section{b. Payment Based Activities}

There is no regulation that prohibits the association organizes activities based on payment. The establishment of associations that are not intended to bring benefits for members does not mean associations must refrain from receiving payment. The purpose of establishment referred to in Indonesia civil code is the aim of the founders. It is not the purpose of associations in performing an activity. The payment received for the activities of associations are acquired by the association and belongs to the assocation. It is put into the association's treasury. The nonprofit purpose of founding an association refered to the intent and purpose of the founders, not of the association. The founders do not make any profit from the association they founded.

The profit-making purpose of founding an entity can be seen, for example, in partnership (maatschap) regulation. Article 1618 of Indonesia civil code defined parnership as "an agreement by which two or more individuals bind themselves to contribute something jointly with the intent of sharing the profit therefrom among one another. (the underline is from the author)". The intent and purpose of the partnership founders are the distribution of profit. Unlike partnership, the intent and purpose of association founders are not distribution of profit of the association. 
The not-for-profit purpose of the founders does not mean the founders intend that the association organizes all activities for free. Speaking economically, organizing activities, even daily operations, of the association spent cost so it is apprehensible that the association asks payment from the activity participants. A professional association which aims to safeguard the profession dignity and capability, for example, organized a seminar for its members with charging fee. A parent sport assocation (perkumpulan induk olahraga) held tournaments with admission fee for audience. To ensure the adequate funds for carrying association activities association, some associations set the amount of fee in such a way that the revenue collected from the participants can exceed the activities cost. The net income is put in treasury to finance the future activities that will be hold by the association.

Activities that are classified as charitable, religious, and humanitarian activities according to the Ministry of Justice can be hold with charging fee as well. There is no legislation that prohibits it. Act No. 20 of 2003 on National Education System permit tuituin fee. Act No. 11 of 2009 on Social Welfare and its implementing regulations do not stipulate that social welfare must be carried out free of charge. In fact, the implementing regulation of the Social Welfare Act, namely Government Regulation No. 39 of 2012 on Social Welfare, regulates minimum standards of facilities and infrastructure of social welfare institutions, e.g care homes, rehabilitation centers, and shelter houses. The standard required for such facilities and infrastructure would not be achieved and maintained if the association only relied on membership fee and donation and did not charge payment from its users.

The Foundation Act does not prohibit the foundation, which is a non-profit entity, from carrying out activities by receiving payments from participants. Rudhi Prasetya said that the meaning of charitable purpose is not that the foundation shall not run any business activities for fund raising. It does not mean that the foundation may only ask donations or alms because this way the foundation could not be well developed. It does not mean that the foundation can not conduct income generating activities either, because this way the foundation would not be able to grow and 
expand. ${ }^{26}$ Although associations are not prohibited to undertake activities by accepting payment, but given the association is not established to obtain profit for its founders, there are limitations on the activities undertaken by the association.

\section{c. Limitation of Implementation of Payment Based Activities}

The associations are founded for purposes other than obtaining profit for its members. Accordingly, the first limitation of payment based activities is the net income the association generated should not be distributed to the members. This limitation distinguishes an association from a partnership (maatschap), a firm (vennotschap onder firma), a limited partnership (commanditaire vennotschap), a limited liability companies (perseroan terbatas), or a cooperatives (koperasi). The net income of the activities organized by the association is used to finance the future activities of the associations. The essence of non profit entity is there is no distribution of profit. In a special committee meeting on the Foundation Bill (rapat pansus pembahasan rancangan undang-undang yayasan), the Government also explained that the term 'non-profit' does not mean not generating any profit. Rather, it means the profit generated would not be shared among its founders or officials. The profit would be used to pursue the foundation objectives. ${ }^{27}$

In the Netherlands association is not prohibited to engage in profit generated activities. The prohibition is on the profit distribution to the members (Article 26 paragraph (3) of INDONESIA CIVIL CODE ). Association may use the profits to finance the activities of associations and to do things other than to distribute it to members. ${ }^{28}$ Likewise, Association Act of France regulates that associations can engage in activities that generate profit, even continuously. However, the profit should not be distributed to the members. ${ }^{29}$ According to the Law of the German

\footnotetext{
${ }^{26}$ Rudhi Prasetya, Yayasan Dalam Teori Dan Prakti (Sinar Grafika 2013).[61].

${ }^{27}$ Transcript of special committee meeting of Foundation Bill on February 7, 2011, the second tape.[4].

28 AG Lubbers, Vereniging En Stichting, Gewoon in Praktijk(WEJ Tjeenk Willink 1986).[19].

${ }^{29}$ Klaus J. Hopt and Thomas Von Hipple (ed), Comparative Governance of Non-Profit Organizations (Cambridge University Press 2010).[273].
} 
Civil Code (Bürgerliches Gesetzbuch), associations which do not aim to conduct business (nicht wirtschaftlicher Verein) should not share the profits to the members without adequate compensation of the members. The associations may carry out economic activites on limited basis, which are 1) the activities are functionally connected to the non-economic activities of the association, 2) the activities only take a subordinated role compared to the non-economic activities of the association. ${ }^{30}$ This restriction is made to protect the interests of creditors of association. According to the courts, an association is allowed to carry out economic activities that are more than just subordinative activities through a limited liability company that is wholly owned by the association. ${ }^{31}$

In the United States associations are not prohibited for to gain profits. The prohibition is on the distribution of profit. ${ }^{32}$ Section 5 (d) of (Revised) Uniform Unincorporated Non Profit Association Act (RUUNAA) governs that associations may engage in profit-making but profits from any activities must be used or set aside for the association's nonprofit purposes. Section 14 (2) of Australian Assocition Incorporation Act regulates that an association is ineglible for incorporation if it is formed or carried on with the object of trading or obtaining pecuniary gain for its members. Nor an association is eglible for incorporation if it is trading or obtaining pecuniary gain for its members. An association may engage in profit-making activities, but it shall not distribute any profit to its members. ${ }^{33}$

Based on comparison of the laws above, it can be concluded that there are similar legal provisions for the association according to legislation, court decisions, and doctrines. The first similarity is that associations are not prohibited from

${ }^{30}$ EJ Cohn (ed), Manual of German Law (Volume 1) (The British Institute of International Comparative Law 1968).[67]. See alsoThomas von Hippel, 'Comparative Governance of NonProfit Organizations' in J. Hopt and Thomas Von Hipple (ed), Nonprofit organisasi in the Germany (Cambridge University Press 2010).[222]. And Winfried Boecken, BGB - Alglemeiner Teil (W Kohlhammer 2007).[66].

31 Thomas von Hippel (n 33).[222-223].

${ }^{32}$ The court's ruling in the 1950 case of the American Jersey Cattle Club vs Glander. Henry Hansmann, 'The Role of the Nonprofit Enterprise' (1980) 89 The Yale Law Journal (Hereinafter Referred to Henry Hansmann I).[838].

33 Andrew Twaits (n 27). [314]. 
carrying out profit-generating activities, even though the types of activities are different in each country. The second similarity is that associations are prohibited from distributing profits to the members. This prohibition is the main criteria for a non-profit or not-for-profit status of an organization in various countries.

The next limitation is that activities carried out by receiving payments should be within the scope of the purpose of the association. An association is established to achieve a purpose. Activities are carried out in order to achieve the association's purpose. Accordingly, charging payments or making an income does not possess any legal problem as long as the activities are conducted to achieve the purpose of the association.

In reality associations conduct occasional or regular activities with receiving payment. Payment based activities can only be carried out regularly if they are necessary for the achievement of association objectives. They could be activities that are generally not deemed as busineess activities, e.g regular training conducted by profesional association with training fee charged. They could be activities that are deemed as business activities too, e.g bakeries, laundries, or automobile repair shop. An association established for social awareness towards the disabled, for example, aims to enhance the life of people with disabilities. To achieve its purpose, besides providing training, the association also conducts a laundry, which employs disabled people. ${ }^{34}$ Although the association charges payment for laundry from its customers, the laundry is needed to achieve the association's purpose.

Van Der Grinten stated that an association may conduct business activities, but the activities are only a tool or a means to achieve its purpose. They should not be the purposes of the association. ${ }^{35}$ That means, first, a business activity can be carried out as long as it is necessary to achieve the association's purpose, or in another words, the activity should be within the scope of the purpose of the association. This is a consequence of the not-for-profit purpose of establishing associations. An activity is conducted to pursue an objective, not vice versa. Therefore, the second

\footnotetext{
${ }^{34}$ W. C. L. Van der Grinten (n 10).Op.Cit.[226].

35 ibid.
} 
meaning is that business should not be an objective in establishing associations. This restriction should be applied in real life practice, that an association should not be founded to pursue business activities.

As mentioned previously, an association requires funding to sustain its existence. There are business activities that are indirectly (economically) beneficial to the achievement of the association's objectives, but not directly. The business activities that are not directly related to the purpose of association can only be done through an incorporated business entity. A non permanent economic activity can be conducted by the association directly. There are some associations in real life that sell souvenirs and other items to get funding. This activity is not the purpose of the association, nor is it the main activity of the association. Given this activity is conducted occasionaly, while a business entity is of permanent nature, the associaton may directly conduct the ocasional economic activity.

Civil Society Organizations Act, ${ }^{36}$ which also governs associations, stipulates that an incorporated Civil Society Organization, even though it is a nonprofit organization, may establish a business entity. Likewise, Bill of Association arranged that an association may establish business entities which are aligned with the association's activities. An association may also invest in a prospective business entities (Article 7). However, this problems may raise few problems. First, although there is a limitation of the amount of capital investments, founding or investing in an unincorporated business entity has a consequence of liability of the association. Unless the association invested as a passive partner in $\mathrm{CV}$ (commanditaire vennotschap), the entire property of the association could be lost in a lawsuit against the unincorporated business entity. It is not right for an association to risk itself to carry out business activities not directly related to the purpose of the association. The risk is worth taking only to conduct a business activity necessarily needed for the achievement of the association objectives. Therefore, the business activity that is not directly related to the purpose of

\footnotetext{
${ }^{36}$ Act No. 17 of 2013 on Civil Society Organization as amended by Act No. 16 of 2017 on the Amendment to Act No. 17 of 2013 on Civil Society Organization .
} 
associations, should be carried out by establishing or investing in incorporated business entity only.

The second problem is, unlike in the Netherlands and Germany, ${ }^{37}$ in Indonesia a business entity ${ }^{38}$ must be founded by two or more persons. As a result, when the association need to conduct a business activity to achieve its purpose, it has to find another person to establish the entity. It is not an easy thing to do. Hence, in practice the association would likely to establish a business entity with one/more of its members. There is also a possibility that the director and other offical positions of the business entity are hold by the persons affiliated with the associaton or its members. These kind of practice would possibly lead to disputes among members of the association, especially in case when one of the members become a founder of the business entity by other members agreement, but in fact, using the association's fund to make contribution (inbreng) to the business entity. Considering the legal problems that may arise from the provision of conducting business activities related to the association's objectives through a business entity, conducting business activities directly by the association would be a better option, as long as they are aligned or needed for the purpose of the association.

\section{Not Distributing Property to its Members}

An association is established because of gathering of two or more people. Over time, an association acquire property to conduct its activities in order to achieve the association purpose. Consequently, the property should only be used to pursue the association purpose. It should not be distributed to the members. Likewise, the net income (profit) generated from association activities are not to

\footnotetext{
${ }^{37}$ See Article 2: 175 paragraph (2) of Indonesia civil code for private limited liability company (besloten vennootschap met beperkte aansprakelijkheid-abbreviated as BV) and Section 2:64 paragraph (2) of $\mathrm{N}$ Indonesia civil code for public limited liability company (Naamloze Vennootschap - abbreviated NV). For private limited company under German law (Gesellschaft mit beschränkter Haftung - abbreviated $\mathrm{GmbH}$ ) see Article 1 of Gesetz betreffend die Gesellschaften mit beschränkter Haftung. For public limited liability company under German law (Aktiengesellschaft abbreviated AG) see Article 2 of Aktiengesetz.

${ }^{38}$ Except for sole propietorship business which is also commonly known as a Usaha Dagang (UD).
} 
be distributed to the members either. It should be used to cover future operational cost of association. In common law system countries, particularly the United States, the ban on distribution of profits to the members of association is called "non-distribution constraint". ${ }^{39}$ Non-distribution constraint is an essential element of non profit organization.

There is an exception to the non disribution constrain. Officers of an association, which also are members of association, could receive reasonable honorary payment in certain cases. According to Hansmann, eventhough an association shall not distribute its profit to its members or officers, it could give reasonable compensation to anyone who gave his service to the association, whether he is a member or not. ${ }^{40}$ In the United States both Section 25 of RUUNAA and Section 6.41 of Model Non Profit Corporation Act permit association give reasonable compensation or renumeration to its members and officers. In Germany an association is prohibited to distribute its property to its members and organs only if the association does not receive adequate compensation ${ }^{41}$

Formerly, the association did not play a significant role in society so that the organ of the associations worked without payment. Nowadays in developed countries associations play a large role in various fields in public sector, e.g. in advocacy, health, education, social welfare, and the environment. ${ }^{42}$ In the Netherlands and Australia, for example, the management board receives remuneration on the management of

\footnotetext{
${ }^{39}$ The term was introduced by Henry Hansmann with the following explanation "A nonprofit organization is, in essence, an organization that is barred from distributing its net earnings, if any, to individuals who exercise control over it, such as members, officers, directors, or trustees. By 'net earnings' I mean here pure profits-that is, excess of the amount needed to pay for services rendered to the organization; in general, a nonprofit is free to pay reasonable compensation to any person for labor or capital that he provides, whether or not that person exercises some control over the organization. It should be noted that a nonprofit is not barred from earning a profit. Many nonprofits in fact consistently show an annual accounting surplus. It is only the distribution of these profits that is prohibited. Net earnings, if any, must be retained and devoted entirely to financing further production of the services that the organization was formed to provide." Henry Hansmann (n 37). Op.Cit.[833].

${ }^{40}$ ibid.

${ }^{41}$ Thomas von Hippel (n 33).[207-222].

${ }^{42}$ Victor R. Fuchs (ed), Individual and Social Responsibility: Child Care, Education, Medical Care, and Long-Term Care in America (Hereinaftere Refered as Henry Hansmann II) (University of Chicago Press 1996).[245-246].
} 
his work, although not all associations do the same. ${ }^{43}$ The management board of an association with a large number of members which actively participate in society, or which requires advanced skills, receive payment.

The management officers are not paid by the association because they are the organ and members of the association. According to non profit principle, a member must not receive any assets of associations. However, on the basis of fairness, officers are entitled to receive reimbursement of the actual costs incurred in managing the association. Based on the same reason, when the association has grown rapidly so that the management tasks has become so complex and time consuming, the officers could receive compensation or honorarium for management tasks performed. The difficulty level, time, quality and quantity of the task and the amount of association's resources should be considered to determine the reasonable amount of the honorarium so it would not contrary to the non profit principle.

Prohibition on the distribution of association property to the members also applys when an association dissolved. A member of association are restrained from receiveing a part of the association's wealth when the association still operates. Like wise, when the association is dissolved, the surplus assets after the liquidation ${ }^{44}$ should not be distributed to the members. If the remaining assets of the dissolved association could be distributed to members, the prohibition on distribution of wealth became meaningless. The members of the association may at any time dissolve the association in order to acquire the association wealth.

Depending on the scope of the activities carried out by an association, the dissolution of an association could be detrimental not only to creditors, but also to

${ }^{43}$ Tymen J. Van Der Ploeg, 'Nonprofit Organizations in the Netherlands' in Klaus J. Hopt and Thomas Von Hipple (ed), Comparative Governance of Non-Profit Organizations (Cambridge University Press 2010).[238].; Ary Burger,[at.al.], The Nonprofit Sector in the Netherlands, Working Document 70 (Sociaal en Cultureel Planbureau 2001).[38-41].; Kerry O'Halloran, [at.al.], Charity Law \& Social Policy: National and International Perspectives on the Functions of the Law Relating to Charities (Springer Science + Business Media 2008).[533].

${ }^{44}$ Liquidation is an action of determining the amount of something (eg accounts) that were previously unclear, debt settlement action, or action/process of converting the assets into cash, particularly to resolve the debt. Bryan A. Garner (ed), Black's Law Dictionary (10th edn, Thomson Reuters 2014).[1015]. As stipulated in Foundation Act, liquidation is the process of settlement activity or wealth. 
the community, especially the service users and other stakeholders. Based on the principle of non-profit and benefits to society, the regulation on remaining assets of a dissolved association could adapt the regulation of foundation. Foundations Act regulates that the remaining assets of a foundation after liquidation were transfered freely to another foundation or any other legal entity which has similar activities. If it can not be done, then the assets were transfered to the State to fincance activities similar to the dissolved foundation (Article 68 of the Foundations Act). Similar provision are also found in Section 45 of Australian Associations Incorporation Act. Adapting Article 68 of the Foundations Act for association is in line the nature of non-profit associations. It could benefit the society as well because the assets can be used by another association to run its activities.

\section{Conclusion}

The conclusion that can be drawn is that an association is of non-profit nature. An association is founded with a purpose other than obtaining profit for its members. The non profit purpose of the association does not mean it can only conduct free activities. Association can also conduct payment based activities as long as it meets these conditions: 1) the activities are directly needed to achieve the association's purpose, 2) the activities are not the objectives of establishing association, 3 ) the activities that are not directly needed to achieve the association's purpose could only carried out ocassionaly or, if permanently, through an incorporated business entity, 4) the income of the activities should not be distributed to the members and the organs.

\section{Bibiography}

Act No. 25 of 1992 on Cooperatives (Gazette of 1992 No. 116, Supplement No. 3502).

Act No. 16 of 2001 on Foundations (Gazette of 2001 No. 112, Supplement No. 4132).

Act No. 20 of 2003 on National Education System (Gazette of 2003 No. 78, 
Supplement No. 4301).

Act No. 28 of 2004 on the Amendment of Act No. 16 of 2001 on Foundations (Gazette of 2004 No. 115, Supplement No. 4430).

Act No. 11 of 2009 on Social Welfare (Gazette of 2009 No. 12, Supplement No. 49 667).

Act No. 17 of 2013 on Civil Society Organization (Gazette of 2013 No. 116, Supplement No. 5430).

Act No. 16 of 2017 on the Amendment to Act No. 17 of 2013 on Civil Society Organization (Gazette of 2017 No. 239, Supplement No. 6139).

AG Lubbers, Vereniging En Stichting, Gewoon in Praktijk (WEJ Tjeenk Willink 1986).

Andrew Twaits, 'The Duties of Officers and Employees in Non-Profit Organizations' (1998) 10 Bond Law Review.

Anwar Borahima, Kedudukan Yayasan Di Indonesia: Eksistensi, Tujuan, Dan Tanggung Jawab Yayasan (Kencana 2010).

Anggela Putri Privitasari, 'Yayasan Pembina Lembaga Pendidikan (YPLP) Pendidikan Tinggi (Dikti) Persatuan Guru Republik Indonesia (PGRI) Provinsi Sumatera Barat 1978-2009' (Universitas Andalas 2011).

Ary Burger, The Nonprofit Sector in the Netherlands, Working Document 70 (Sociaal en Cultureel Planbureau 2001).

Bryan A. Garner (ed), Black's Law Dictionary (10th edn, Thomson Reuters 2014).

Burgerlijk Wetboek voor Indonesie (Gazette of 1847 No. 23).

Chatamarrasjid Ais, Badan Hukum Yayasan (Revised, Citra Aditya Bakti 2006).

EJ Cohn (ed), Manual of German Law (Volume 1) (The British Institute of International Comparative Law 1968).

G.J.H. van der Sangen, 'Rechtskarakter En Financiering van de Cooperatie : Een Onderzoek Naar de Civielrechtelijke Kenmerken van de Cooperatie in Het Licht van de Vraag of Daaruit Beperkingen Voortvloeien Voor de Financiering van Haar Ondernemingsactiviteiten' (Universitas Amsterdam 1999).

Henry Hansmann, 'The Role of the Nonprofit Enterprise' (1980) 89 The Yale Law 
Journal (Hereinafter Referred to Henry Hansmann I).

Herlien Budiono, 'Beberapa Catatan Mengenai Perkumpulan', Kumpulan Tulisan Hukum Perdata di Bidang Kenotariatan (Citra Aditya Bakti 2008).

Kerry O'Halloran, Charity Law \& Social Policy: National and International Perspectives on the Functions of the Law Relating to Charities (Springer Science + Business Media 2008).

Klaus J. Hopt and Thomas Von Hipple (ed), Comparative Governance of Non-Profit Organizations (Cambridge University Press 2010).

Novita Risdiana Anggraini Ningsih and Suparwoto, 'Perkumpulan Pembina Lembaga Pendidikan Dasar Dan Menengah Persatuan Guru Republik Indonesia (PPLP Dasmen PGRI) Jawa Timur Tahun 2002-2005' (2014) 2 Avatara.

Regulation of the Minister of Law and Human Rights No. 3 of 2016 on the Procedures for Incorporation and Approval of Amendments of Statutes of Association (BN No. 115of 2016).

Rudhi Prasetya, Yayasan Dalam Teori Dan Prakti (Sinar Grafika 2013).

Thomas von Hippel, 'Comparative Governance of Non-Profit Organizations' in J. Hopt and Thomas Von Hipple (ed), Nonprofit organisasi in the Germany (Cambridge University Press 2010).

Tim Penyusun Kamus Pusat Pembinaan dan Pengembangan Bahasa, Kamus Besar Bahasa Indonesia (Balai Pustaka 1989).

Tymen J. Van Der Ploeg, 'Nonprofit Organizations in the Netherlands' in Klaus J. Hopt and Thomas Von Hipple (ed), Comparative Governance of Non-Profit Organizations (Cambridge University Press 2010).

Victor R. Fuchs (ed), Individual and Social Responsibility: Child Care, Education, Medical Care, and Long-Term Care in America (Hereinaftere Refered as Henry Hansmann II) (University of Chicago Press 1996).

W. C. L. Van der Grinten, Mr. C. Asser's Handleiding Tot de Beoefening van Het Nederlands Burgerlijk Recht: Personenrecht (Hereinafter Referred to as WCL van Der Grinten II) (WEJ Tjeenk Willink 1968).

—- Vertegenwoordiging En Rechtspersoon: De Rechtspersoon (Hereinafter Referred to as WCL van Der Grinten I) (WEJ Tjeenk Willink 1976). 
Winfried Boecken, $B G B$ - Alglemeiner Teil (W Kohlhammer 2007).

Wirjono Prodjodikoro, Hukum Perkumpulan, Perseroan, Dan Koperasi Di Indonesia (Dian Rakjat 1969).

HOW TO CITE: Paula, 'Non-Profit Nature of Associations (Vereniging)' (2019) 34 Yuridika. 
--This page is intentionally left blank-- 